\title{
Karakteristik Equatorial Plasma Bubbles (EPB) dari Pengamatan Radar Atmosfer Equator (EAR)
}

\author{
Dyah Rahayu Martiningrum* \\ Pusat Sains Antariksa LAPAN, Jl. Dr. Junjunan No. 133 Bandung-40173, Indonesia \\ Jurusan Teknik Komunikasi dan Komputer, Fakultas Informatika, Universitas Kyoto, Jepang
}

\section{Intisari}

Fenomena-fenomena seperti Equatorial Plasma Bubbles/Equatorial Spread F (EPB/ESF) dan Equatorial Ionization Anomaly (EIA) sangat berpotensi terjadi di wilayah atmosfer atas Indonesia (ionosfer) yang terletak dalam zona aktif gangguan lapisan ionosfer, yaitu dalam rentang $+15^{\circ}$ lintang geomagnet. Fenomena-fenomena tersebut akan mengganggu beroperasinya sistem komunikasi radio maupun satelit berupa adanya gangguan dalam amplitudo maupun fase dari gelombang radio yang diterima penerima di bumi, dikenal dengan istilah sintilasi. Dalam penelitian ini dibahas beberapa karakteristik penting yang teramati oleh sistem Equatorial Atmosphere Radar yang telah dioperasikan di Kototabang $\left(0,20^{\circ} \mathrm{S}, 100,32^{\circ} \mathrm{E} ; 10,36^{\circ} \mathrm{S}\right.$ dip lat $)$. Sistem antenna Radar disusun sedemikian sehingga mampu mengamati gangguan lapisan ionosfer yang terjadi tegak lurus terhadap garis-garis medan magnet, teramati sebagai Field Aligned Irregularities (FAI). Berdasarkan hasil pengolahan data diperoleh dua macam gelembung plasma yaitu post-sunset dan post-midnight yang keduanya dikendalikan oleh mekanisme fisis yang berbeda. Variasi musiman kejadian kedua jenis ketidakteraturan plasma tersebut juga ditampilkan dalam makalah ini. Bulan-bulan equinox (Maret-April atau September-Oktober) adalah bulanbulan dimana post-sunset FAI terjadi lebih sering dibanding post-midnight. Sementara bulan-bulan solstice (Desember-Januari atau Juni-Juli) adalah bulan-bulan dimana post-midnight FAI lebih sering terjadi. Gambaran tentang arah penjalaran memberikan pemahaman baru tentang bagaimana perkembangan ketidakteraturan yang terjadi waktu ke waktu, baik secara horizontal maupun vertikal. Hasilnya memberi gambaran lebih baik tentang mekanisme kejadian EPB/ESF yang sangat bermanfaat dalam pengembangan model ketidakstabilan plasma, serta untuk melengkapi hasil pengamatan peralatan lain yang sudah ada.

\begin{abstract}
Phenomena such as Equatorial Plasma Bubbles/Equatorial Spread F (EPB/ ESF) and the Equatorial Ionization Anomaly (EIA) was potentially occured in the Indonesian region of the upper atmosphere (ionosphere) located in the active zone ionosphere disturbances, that is in the range of $+15^{\circ}$ latitude geomagnetic. These phenomena would disrupt the operation of radio and satellite communications systems in the form of a disturbance in the amplitude and phase of the received radio wave receivers on Earth, known as scintillation. In this study addressed several important characteristics observed by the Equatorial Atmosphere Radar system that has operated in Kototabang $\left(0.20^{\circ} \mathrm{S}, 100.32^{\circ} \mathrm{E} ; 10.36^{\circ} \mathrm{S}\right.$ dip lat). Radar antenna system is arranged so that is able to observe the ionosphere interference that occurs perpendicular to the magnetic field lines, is observed as a Field Aligned irregularities (FAI). From EAR data analysis obtained two types of plasma bubbles post-sunset and post-midnight which is driven by two kinds of different physical mechanisms. Seasonal variation of both plasma irregularities are discussed in this paper. In equinox months (March-April or September-October), post-sunset are frequently occurred rather than post-midnight. While in solstice months (December-January or June-July) post-midnight are frequently occurred. The propagation direction provide more detail explanation related to development of irregularities time by time horizontally and vertically. The results not only suggested the better understandings of mechanism of EPB/ESF occurrence, but also contributed on development of plasma instability model and supported observations by other instrument which have already operated.
\end{abstract}

KATA KUNCI: characteristics, Equatorial Plasma Bubbles (EPB), Equatorial Atmosphere Radar (EAR)

\section{PENDAHULUAN}

Atmosfer yang melingkupi bumi kita terdiri dari beberapa lapisan. Lapisan-lapisan tersebut selain ditinjau dari perbedaan temperatur terhadap ketinggian, dapat juga ditinjau dari perbedaan kerapatan elektron terhadap ketinggian.

\footnotetext{
*E-MAIL: dyah.rahayu@lapan.go.id
}

Lapisan itulah yang dikenal dengan lapisan ionosfer. Lapisan ionosfer mulai menarik untuk dikaji ketika Booker dan Wells pada tahun 1938 [1] menemukan adanya trace tidak biasa dari pantulan gelombang radio yang diterima alat ionosonda, yang sekarang kita kenal sebagai Equatorial Spread F (ESF). Berbagai peralatan kemudian digunakan untuk mengamati karakteristik dari ESF, beberapa diantaranya dengan memanfaatkan VHF Radar, GPS, Roket, Satelit, dan ionosonda [2-8].

Selain karakteristik dari ESF, hal lain yang tidak kalah penting adalah memahami bagaimana mekanisme fisis yang 


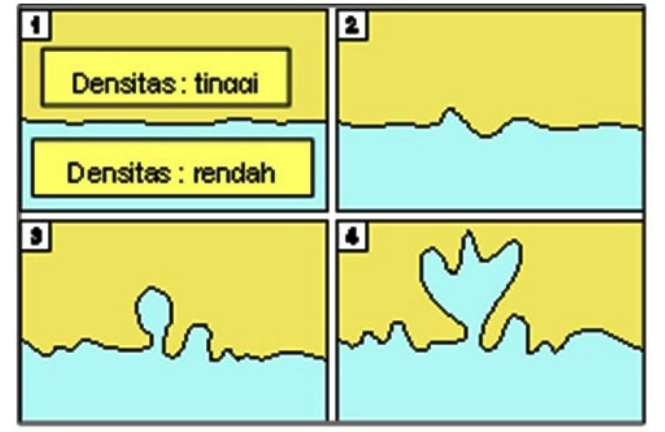

Gambar 1: Ilustrasi pembentukan equatorial plasma bubbles di lapisan F Ionosfer.

mengontrol terjadinya ESF. Sejauh ini, mekanisme yang diyakini bertanggungjawab dalam terjadinya ketidakteraturan di lapisan ionosfer ialah apa yang dikenal dengan teori ketidakstabilan Rayleigh Taylor [9]. Ketidakstabilan lapisan ionosfer di daerah ekuator dimulai tidak lama setelah matahari terbenam, dimana penipisan kerapatan elektron dalam skala yang besar terjadi di bagian bawah lapisan $\mathrm{F}$ ionosfer. Gelembung plasma dengan kerapatan elektron lebih kecil mendorong ke lapisan dengan kerapatan elektron yang lebih besar. Gelembung-gelembung plasma tersebut, kita kenal sebagai Equatorial Plasma Bubbles (EPB) yang kemudian terus naik dan berkembang ke ketinggian lebih tinggi dan terjadi sampai beberapa jam. Gelembung-gelembung plasma inilah yang kemudian menyebabkan terjadinya ketidakteraturan plasma di lapisan ionosfer (Gambar 1).

EPB berkembang dalam skala dari $10 \mathrm{~cm}$ sampai dengan $1000 \mathrm{~km}$, berpotensi mengganggu sistem komunikasi dan sistem navigasi pada daerah di sekitar \pm 20 derajat lintang geomagnet ekuator. Saat EPB berkembang, maka sinyal gelombang radio yang menjalar melalui daerah tersebut akan mengalami gangguan. Gangguan tersebut teramati dari alat ionosonda berupa spreading frekuensi, ketinggian, ataupun keduanya (frekuensi dan ketinggian), sehingga fenomena ini dinamakan juga sebagai ESF. Di samping itu, ketika gelombang radio menjalar melalui EPB/ESF, maka amplitudo dan fasenya akan terganggu sehingga menyebabkan terjadinya sintilasi. Demikian pentingnya memahami ketidakteraturan lapisan ionosfer dalam kajian cuaca antariksa sehingga sampai saat ini pun pertanyaan-pertanyaan terkait fenomena ini tetap menarik untuk dipecahkan.

Penelitian ini bertujuan untuk memahami karakteristik dari Equatorial Plasma Bubbles dari pengamatan EAR yang telah dioperasikan di Kototabang.

\section{METODOLOGI}

Radar atmosfer ekuator (EAR) adalah radar VHF (47 MHz) yang dioperasikan di Kototabang $\left(0,20^{\circ} \mathrm{S}, 100,32^{\circ} \mathrm{E} ; 10,36^{\circ} \mathrm{S}\right.$ dip lat) untuk mengamati dinamika lapisan atmosfer dari beberapa kilometer sampai ratusan kilometer di atas permukaan tanah. Radar atmosfer ekuator memanfaatkan antenna yang berbentuk quasi-circular array dengan garis tengah mendekati $110 \mathrm{~m}$ dan terdiri dari 560 antenna Yagi 3 elemen. Sistem phased array dalam antenna bersifat aktif dengan masingmasingnya dilengkapi dengan modul pemancar dan penerima (TR module). Sistem antenna dan spesifikasi radar atmosfer dapat dilihat pada Gambar 2.

Secara sederhana, sistem kerja radar atmosfer ekuator adalah dengan memancarkan gelombang radio ke atas melewati berbagai lapisan atmosfer dengan kerapatan yang berbeda-beda, kemudian dihamburkan oleh lapisan atmosfer, termasuk lapisan ionosfer, dan sebagian sinyalnya akan diterima kembali oleh antenna penerima radar. Echoes scatter radar inilah yang akan memberikan informasi karakteristik ketidakteraturan yang terjadi di lapisan ionosfer. Pada kondisi tertentu yaitu saat perubahan siang hari menjadi malam hari terjadi interaksi antara garis-garis medan listrik yang berarah timur-barat dengan garis-garis medan magnet sepanjang wilayah ekuator. Garis-garis medan listrik yang berarah ke timur pada siang hari dan segera berubah kearah barat pada malam hari menyebabkan ketidakstabilan plasma di lapisan ionosfer seperti telah dijelaskan pada bab Pendahuluan. Ketidakstabilan plasma atau ketidakteraturan di lapisan ionosfer yang berarah tegak lurus terhadap arah garis-garis medan magnet (B) kita kenal sebagai Field Aligned Irregularities (FAI). Radar atmosfer ekuator dapat dimanfaatkan untuk penelitian ketidakteraturan lapisan ionosfer tersebut dengan cara mengatur posisi keenambelas beamnya (Gambar 3).

Ada tiga macam data yang dapat diperoleh dari pengamatan radar, yaitu Echo Power, Spectral Width, dan Radial Doppler Velocity dari hamburan sinyal gelombang radio yang dipancarkan radar. Pada penelitian ini hanya digunakan data echo power untuk mendapatkan gambaran karakteristik EPB di atas Kototabang, dengan tahapannya sebagai berikut:

- Data echo power ditampilkan dalam bentuk grafik Range-Time-Intensity (RTI), dengan Range adalah jarak antara posisi radar dengan ketinggian gangguan/gelembung plasmanya (bubbles), Time adalah waktu lokal dimana radar dioperasikan, dan Intensity, adalah intensitas echo scatter radar. Salah satu contoh grafiknya dapat dilihat pada Gambar 3.

- Karena gangguan plasmanya terjadi di lintang 0 geomagnet (ekuator) dan menjalar secara horosontal maupun vertikal, sementara lokasi radar tidak tepat di lintang 0, maka sesungguhnya diperlukan konversi dari data Range ke dalam ketinggian yang sebenarnya terjadi di lintang 0 tersebut, yang biasa dikenal sebagai ketinggian Apex.

- Langkah selanjutnya adalah membuat peta dua dimensi dari gangguan/gelembung plasma yang diproyeksikan dari posisi vertikal terhadap bidang horizontal setiap selang waktu tertentu. Ketika peta-peta tersebut untuk selang waktu tertentu disajikan secara berurutan, maka akan diperoleh informasi tentang arah penjalaran gangguan tersebut.

- Hasil berupa arah penjalaran gangguan/gelembung plasma di lapisan ionosfer tersebut akan lebih jelas lagi 


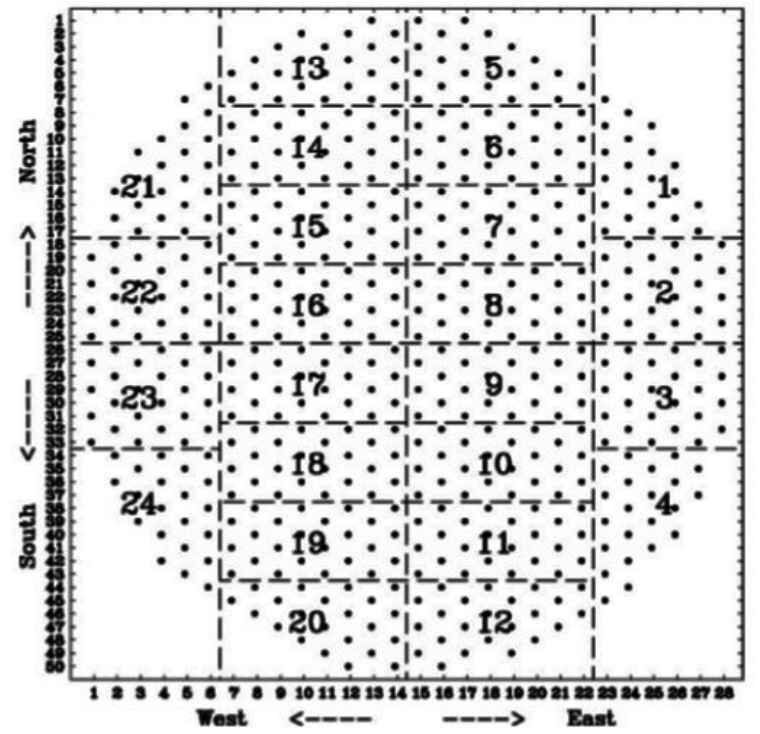

(a)

\begin{tabular}{|c|c|}
\hline Item & Specification \\
\hline Location: & $\begin{array}{l}0.20^{\circ} \mathrm{S}, 100.32^{\circ} \mathrm{E} \\
865 \mathrm{~m} \text { above sea level }\end{array}$ \\
\hline $\begin{array}{l}\text { Geomagnetic latitude } \\
\text { and longitude: }\end{array}$ & $10.63^{\circ} \mathrm{S}, 171.93^{\circ} \mathrm{E}$ \\
\hline Radar system: & Monostatic pulse Doppler radar \\
\hline Operating frequency: & $47.0 \mathrm{MHz}$ \\
\hline Antenna: & $\begin{array}{l}\text { Quasi-circular antenna array of } \\
560 \text { three-element Yagi antennas }\end{array}$ \\
\hline Aperture: & $110 \mathrm{~m}$ in diameter \\
\hline Beam width: & $3.4^{\circ}$ (half power width; one way) \\
\hline $\begin{array}{l}\text { Beam direction } \\
\text { in avimuth: }\end{array}$ & $0-360^{\circ}$ in $0.1^{\circ}$ steps \\
\hline $\begin{array}{l}\text { Beam zenith angle: } \\
\text { Gain: }\end{array}$ & $\begin{array}{l}0-30^{\circ} \text { in } 0.1^{\circ} \text { steps (no grating lobe) } \\
33 \mathrm{dBi}\end{array}$ \\
\hline \multicolumn{2}{|l|}{ Transmitter } \\
\hline Peak power: & $100 \mathrm{~kW}$ (sum of all TR modules) \\
\hline Average power: & $5 \mathrm{~kW}$ (max; sum of all TR modules) \\
\hline Number of TR modules: & 560 units (same as Yagi antennas) \\
\hline $\begin{array}{l}\text { Single TR module's } \\
\text { power: }\end{array}$ & 180 W/unit \\
\hline Pulse width: & $0.5-256 \mu \mathrm{s}$ \\
\hline IPP: & 200 ps-10 ms (variable in 200 ps steps) \\
\hline \multicolumn{2}{|l|}{ Receiver } \\
\hline Type: & Single super heterodyne \\
\hline Noise figure: & $5 \mathrm{~dB}$ (TR modules) \\
\hline Pulse compression: & $\begin{array}{l}\text { Barker, complementary and } \\
\text { Spano codes ( } 1 \text { to } 16 \text { bits) }\end{array}$ \\
\hline Subpulse width: & $0.5,1.0,2.0,4.0,8.0,16.0$ us (variable) \\
\hline Dynamic range: & $70 \mathrm{~dB}$ \\
\hline A/D converter: & 14 bits \\
\hline Number of range gates: & $256(\max )$. \\
\hline
\end{tabular}

(b)

Gambar 2: Sistem antenna Yagi (kiri) dan spesifikasi EAR Kototabang (kanan) [2].

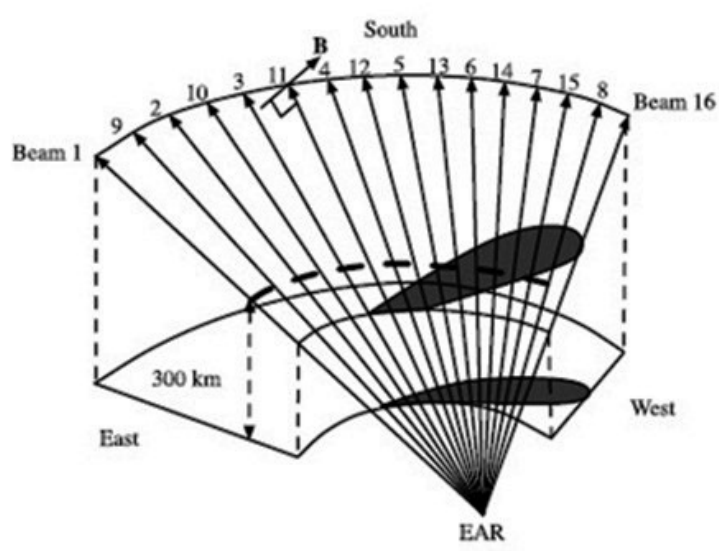

Gambar 3: Ilustrasi sistem EAR Kototabang [10].

bila ditampilkan dalam bentuk animasi dari beberapa grafik dua dimensi pada selang waktu tertentu.

- Tahapan terakhir adalah menghitung frekuensi kejadian ketidakteraturan di lapisan ionosfer. Dari hasil simulasi sederhana, diperoleh nilai threshold sebesar $-5 \mathrm{~dB}$, sehingga perbandingan antara banyaknya sinyal pada range tertentu terhadap banyaknya sinyal yang dihamburkan ke sistem antena secara keseluruhan dapat dihitung.

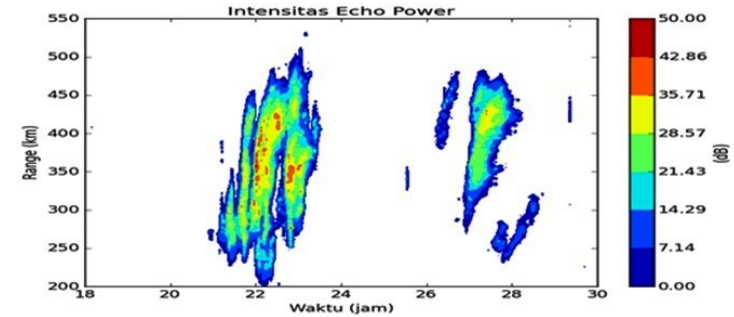

Gambar 4: Tipe FAI lapisan F ionosfer,data 3 Juni 2012.

Tahapan-tahapan tersebut dilakukan untuk semua data pengamatan yang diperoleh selama tahun 2011 sampai dengan 2012.

\section{HASIL DAN PEMBAHASAN}

\section{Morfologi Field Aligned Irregularities (FAI) sebagai indikator ketidakstabilan lapisan ionosfer}

Equatorial Atmosphere Radar (EAR) mampu mengamati ketidakteraturan di lapisan ionosfer yang berarah tegak lurus terhadap arah garis-garis medan magnet (B) dari intensitas echo scatter yang diterima kembali oleh sistem antenna 

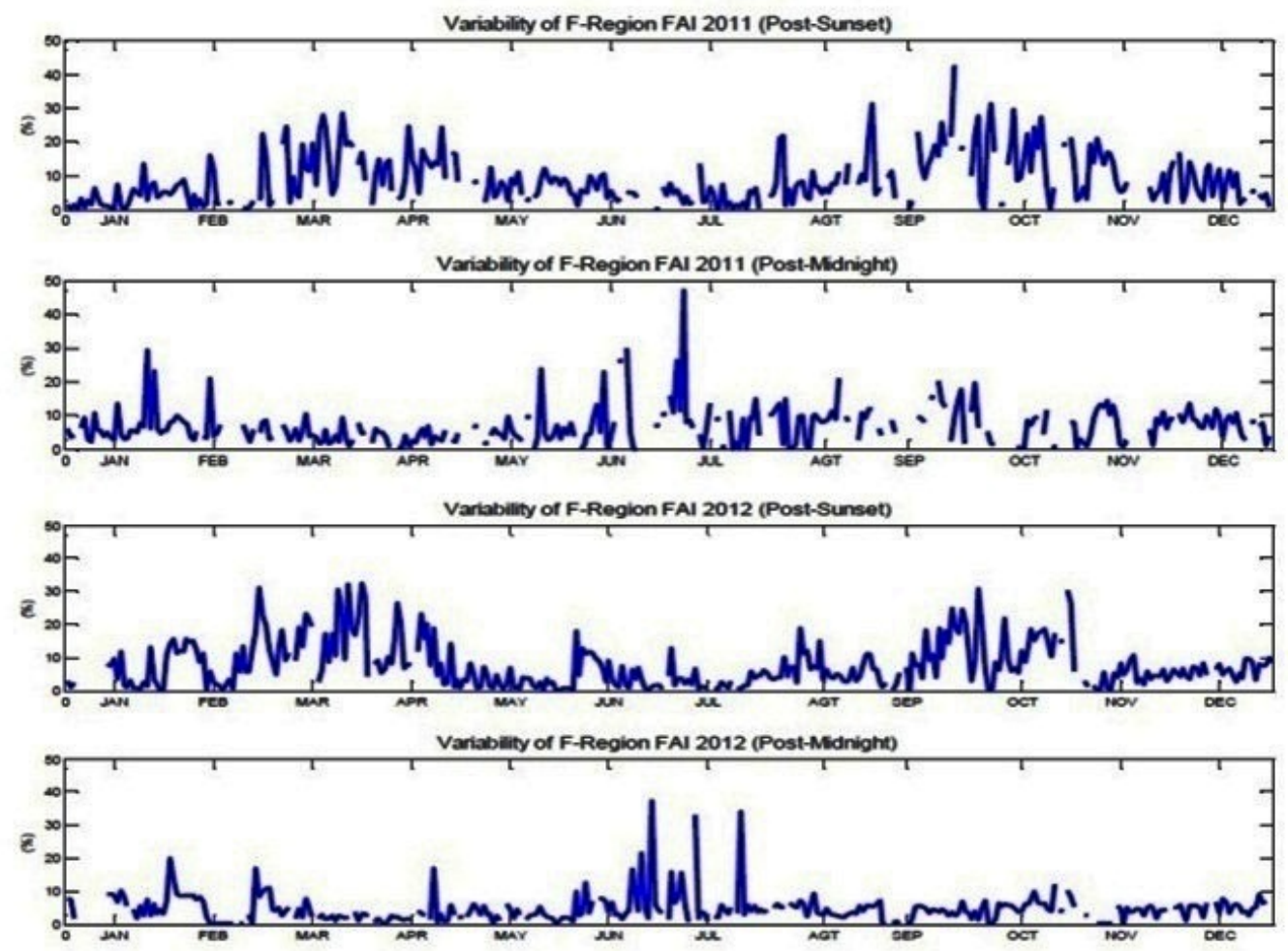

Gambar 5: Prosentase kejadian EPB/ESF selama 2011-2012.

radar. Hasil plotting intensitas echo scatter biasa ditampilkan dalam bentuk grafik RTI (Range-Time-Intensity). Sepanjang tahun 2011-2012 teramati ada dua jenis gelembung plasma yang berkembang yaitu post-sunset dan post-midnight (Gambar 4). Sesuai dengan namanya, post-sunset terjadi tidak lama setelah matahari terbenam, sedangkan post-midnight terjadi setelah tengah malam sampai pagi.

FAI tipe post-sunset berkaitan dengan adanya kenaikan bagian bawah lapisan $\mathrm{F}$ ionsofer pada malam hari yang dikenal dengan istilah Pre Reversal Enhancements (PRE), sehingga menimbulkan terjadinya kecepatan pergeseran vertikal [11]. Dalam kondisi demikian, lapisan ionosfer akan dengan cepat naik dan frekuensi tumbukan menjadi rendah, sehingga memicu terjadinya ketidakstabilan Rayleigh Taylor [12]. Lain halnya dengan FAI tipe post-midnight yang terjadi karena adanya gelembung plasma yang sudah terbentuk sebelumnya di tempat lain, dan terbawa oleh penjalaran drift dalam arah timur-barat, juga oleh proses lain yang terjadi selama periode post midnight. Intensitas kejadiannya berbanding terbalik dengan solar flux $[13,14]$.

\section{Variasi FAI lapisan F ionosfer}

Karakteristik EPB dapat digambarkan oleh variasi FAI yang teramati Radar EAR. Dengan menentukan threshold tertentu dari data intensitas echo power, maka akan diperoleh prosentase kejadian EPB/ESF dalam selang waktu tertentu. Dalam penelitian ini digunakan nilai threshold sebesar $-5 \mathrm{~dB}$, sehingga akan dapat dihitung prosentase kejadian dari perbandingan antara banyaknya sinyal pada range tertentu terhadap banyaknya sinyal yang dihamburkan ke sistem antena secara keseluruhan.

Untuk data tahun 2011-2012, variasi musiman kejadian EPB/ESF dapat dilihat pada Gambar 5. post-sunset FAI lebih banyak terjadi pada bulan-bulan equinox, saat matahari berada dekat dengan ekuator (Maret-April, September-Oktober) yaitu mencapai 30-40\% dan post-midnight FAI banyak terjadi di bulan-bulan solstice (Juni-Juli) yaitu mencapai 35-50\%.

Prosentase kejadian FAI sekaligus indikator prosentase kejadian EPB/ESF ini, menguatkan beberapa hasil penelitian sebelumnya berkaitan dengan variasi musiman kejadian FAI baik secara longitudinal [15], karena pengaruh aktivitas matahari $[16,17]$, karena angin meridional [18], maupun variasi akibat deklinasi medan magnet bumi [19].

\section{Arah penjalaran FAI lapisan $F$ ionosfer}

Selain morfologi dan variasi dari ketidakteraturan di lapisan $\mathrm{F}$ ionosfer, perlu dipahami juga bagaimana penjalaran ketidakteraturan tersebut. Hal ini penting untuk memahami proses fisis yang berperan dalam pembetukan dan perkembangan plasma bubbles. Apalagi penjalaran baik dalam arah vertikal maupun longitudinal akan membantu kita memahami bagaimana sebenarnya variasi harian EPB/ESF, khususnya dalam penelitian ini adalah dari analisis FAI hasil pengamatan radar EAR. Sampai saat ini, memang variasi harian 

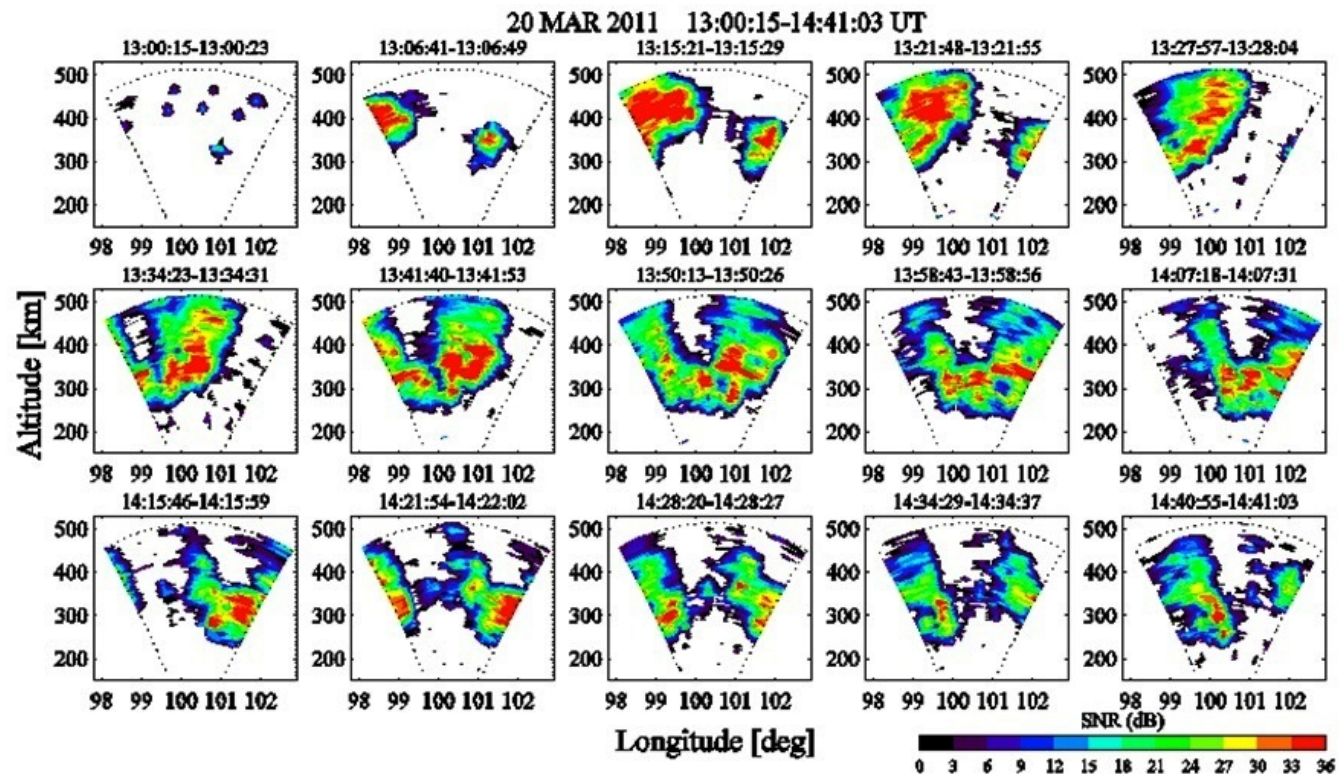

Gambar 6: Peta fan sector FAI lapisan F menggambarkan perkembangan Equatorial Plasma Bubbles dari waktu ke waktu.

ini masalah utama terkait EPB/ESF yang belum dapat dipecahkan.

Dari setiap kejadian FAI yang terekam oleh radar EAR, kemudian diplot dalam suatu bidang yang dinamakan fansector karena memang bentuknya yang mirip dengan kipas mengikuti arah dari keenambelas beam antenna radar. Sebagai contoh, Gambar 6 menunjukkan peta fan-sector untuk kejadian EPB tanggal 20 Maret 2011. Dari gambar tersebut terlihat jelas bagaimana gelembung plasma melintasi daerah yang tertangkap oleh sistem antenna radar. Sekitar jam 13:00 UT atau jam 20:00 LT EPB mulai terbentuk dan berkembang semakin besar dan bergerak baik dalam arah timur-barat maupun dalam arah vertikal. Selang pengamatan sekitar 6 menit memberi gambaran arah penjalaran EPB dari sebelah barat ke arah timur dan berlangsung selama hampir dua jam sampai jam 14:40 UT atau jam 21:40 LT.

Selama tahun 2011-2012 teramati sebanyak 236 hari kejadian EPB. Masing-masing kemudian diplot dalam peta fan sector seperti pada Gambar 6 sehingga bisa ditentukan arah penjalaran EPB secara longitudinal. Frekuensi kejadian penjalaran EPB dalam arah timur ataupun barat dapat dilihat pada Gambar 7. Arah penjalaran terbanyak adalah ke arah timur. Hasil ini mendukung hasil-hasil sebelumnya tentang adanya penjalaran EPB yang berarah timur-barat. Variasi EPB dalam arah timur barat penting untuk dipahami terutama variasi hariannya, karena variasi harian EPB akan memberi jawaban atas pertanyaan-pertanyaan yang terkait ESF dan yang terkait ketidakteraturan lapisan ionosfer pada umumnya.

Beberapa penelitian sebelumnya menunjukkan bahwa ketidakstabilan di lapisan ionosfer terjadi sesaat setelah matahari terbenam. Pada kondisi tersebut terjadi perubahan yang significant terhadap radiasi matahari akibat perubahan siang hari ke malam hari. Proses fotoinisasi yang berubah menjadi rekombinasi menyebabkan perubahan juga terhadap dis-

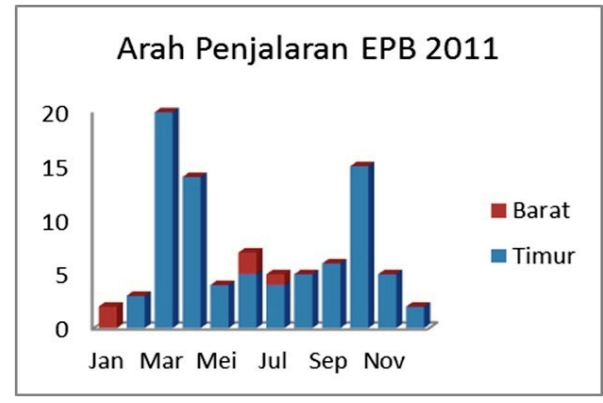

(a)

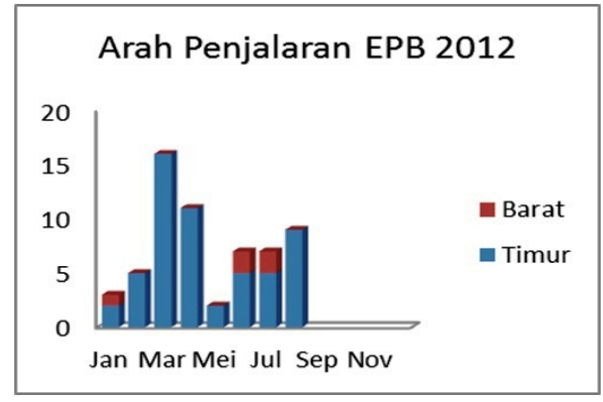

(b)

Gambar 7: Arah penjalaran EPB Tahun 2011-2012.

tribusi kerapatan elektron di lapisan ionosfer. Konduktivitas listrik di lapisan E secara cepat menurun dan medan listrik ke arah timur di lapisan F meningkat sehingga kerapatan plasma juga berubah secara cepat terhadap perubahan ketinggian [20, 21]. Di bagian bawah lapisan ionosfer terjadi kenaikan lapisan, dikenal dengan istilah Post Sunset Rise (PSSR) yang terus berlanjut menjadi Pre Reversal Enhancement (PRE), yang menjadi indikator penting dalam pemben- 
tukan EPB/ESF. Sampai saat ini para peneliti masih belum mendapat jawaban terkait variasi harian dari PRE walaupun variasi musiman dan variasi terhadap aktivitas matahari telah lama diketahui [22].

\section{SIMPULAN}

Demikian kompleks mekanisme yang terlibat dalam proses-proses fisis ketidakstabilan dan ketidakteraturan di lapisan ionosfer melibatkan kombinasi antara elektrodinamik dan dinamika lapisan atmosfer akibat gaya gravitasi. Beberapa pertanyaan telah mampu dijawab dari hasil-hasil penelitian yang sudah dilakukan, terutama yang terkait dengan variasi ketidakteraturan lapisan ionosfer yang sifatnya musiman atau variasi yang tergantung dengan aktivitas matahari. Variasi yang sifatnya lokal/regional dalam arah timur-barat juga telah banyak diketahui dari berbagai peralatan pengamatan lapisan ionosfer seperti ionosonda, GPS, roket, Radar.

Tulisan ini menitikberatkan pada hasil-hasil yang diperoleh dari pengamatan perangkat Radar Atmosfer Ekuator (EAR), berupa morfologi EPB dari analisis intensitas sinyal yang dihamburkan kembali oleh Radar, variasi musimannya, dan juga arah dari penjalarannya secara horizontal-zonal (timur-barat) dan vertikal. Radar membantu menjelaskan morfologi dan perkembangan dari EPB yang tidak dapat dihasilkan oleh peralatan lainnya.

Sepanjang tahun 2011-2012 teramati ada dua jenis gelembung plasma yang berkembang yaitu post-sunset dan postmidnight. Sesuai dengan namanya, post-sunset terjadi tidak lama setelah matahari terbenam, sedangkan post-midnight terjadi setelah tengah malam sampai pagi. post-sunset FAI lebih banyak terjadi pada bulan-bulan equinox, saat matahari be- rada dekat dengan ekuator (Maret-April, September-Oktober) yaitu mencapai 30-40\% dan post-midnight FAI banyak terjadi di bulan-bulan solstice (Juni-Juli) yaitu mencapai 35-50\%. Sedangkan arah penjalaran terbanyak adalah ke arah timur.

Jangkauan sistem antenna peralatan Radar yang terbatas memerlukan dukungan peralatan lain untuk menjelaskan evolusi dari EPB dari waktu ke waktu yang penting untuk memahami variasi harian dari EPB. Peralatan tersebut antara lain adalah peralatan penerima GPS yang mampu mengisi data di daerah dimana perkembangan fenomena EPB tidak terekam oleh Radar. Peralatan lain yang dapat juga digunakan adalah ionosonda (Radar HF) yang secara simultan dari beberapa titik mampu menggambarkan dinamika dan perubahan ketinggian lapisan ionosfer yang menjadi indikator terjadinya ketidakstabilan di lapisan ionosfer.

Penelitian lebih lanjut diperlukan untuk melihat keterkaitan berbagai karakteristik EPB yang diperoleh dari pengamatan Radar EAR dengan berbagai gangguan di lapisan ionosfer yang terdeteksi peralatan lain yang dioperasikan LAPAN seperti ionosonda dan penerima sinyal GPS (GISTM) sehingga akan menjawab pertanyaan terkait variasi harian $\mathrm{EPB} / \mathrm{ESF}$.

\section{Ucapan Terima Kasih}

Ucapan terima kasih penulis sampaikan kepada jajaran struktural LAPAN yang sudah memberi kesempatan untuk studi di Kyoto University. Penulis juga mengucapkan terima kasih kepada Prof. Mamoru Yamamoto atas bimbingan dan arahannya, kepada DR. Tatsuhiro Yokoyama yang banyak membantu dalam pengolahan data dan analisisnya, kepada RISH Kyoto University dan LAPAN atas akses data Radar EAR Kototabang.
[1] H.G. Booker, and H.W. Wells, Terr. Magn. Atmos. Elect., 43(3), 249 (1938).

[2] S. Fukao, et al., Ann. Geophys., 24, 1411-1418 (2006).

[3] G. Li, et al., Journal of Geophysical Research , 118, 6544-6557 (2013), doi: 10.1002/jgra.50581.

[4] Y. Jiao, et al., Radio Science, 48, 698-708 (2013), doi: 10.1002/2013RS005259.

[5] S. Priyadarshi, Surv. Geophys, 36, 295-324 (2015), doi: 10.1007/s10712-015-9319-1.

[6] C.H. Lin, et al., Ann. Geophys., 32, 1145-1152 (2014).

[7] J. Park, et al., Earth Planets Space, 65, 1333,1344 (2013).

[8] G. Li, et al., Journal of Geophysical Research, 117, A08321 (2012), doi:10.1029/2012JA017820.

[9] M.C. Kelley, The Earth's Ionosphere: Plasma Physics and Electrodynamics(Int. Geophys. Ser., 43, Elsevier, New York, 2009).

[10] S. Saito, et al., Journal of Geophysical Res., 113, A11318 (2008), doi:10.1029/2008JA013118

[11] J.V. Eccles, et al., Journal of Geophysical Research: Space Physics, 120(6), 4950-4970 (2014), doi: 10.1002/2014JA020664.

[12] R.T Tsunoda, Progress in Earth and Planetary Science, 2 (2015).

[13] M.A. Abdu, Indian Journal of Radio \& Space Physics, 41, 168-
183 (2012).

[14] G. Li, et al., Journal of Geophysical Research, 116, A04318 (2011), doi: 10.1029/2010JA016056.

[15] T.L. Hoang, et al., Advances in Space Research, 45(3), 351-360 (2010).

[16] T. Yokoyama, et al., Journal of Geophisical Research, 116, A11325 (2011), doi:10.1029/2011JA016797.

[17] D.R. Martiningrum, Jurnal Sains Dirgantara, 9(2), 147-156 (2012).

[18] G. Manju, et al., Indian Journal of Radio \& Space Physics, 41, 240-246 (2012).

[19] M.A. Abdu, I.S. Batista, and J.H.A. Sobral, J. Geophys. Res., 97, 14,897 (1992).

[20] R.F. Woodman, J. Geophys. Res., 75, 6249-6259 (1970), doi: 10.1029/JA075i031p06249.

[21] G. Haerendel, and U.V. Eccles, J. Geophys. Res., 97, 11811192 (1992).

[22] R.T Tsunoda, On the Importance of Instrument Clusters For Equatorial Spread F Studies, International Symposium on the $10^{\text {th }}$ Anniversary of the Equatorial Atmosphere Radar (EAR), Jakarta, September 22-23, 2011, ISBN. 978-979-1458-52-8 (2012). 